\title{
THE THEOLOGY OF DEUTERONOMY 27
}

\author{
Paul A. Barker
}

\section{Summary}

The problems of unity in Deuteronomy 27 are usually treated diachronically resulting in an impoverished theological appreciation of the chapter. Rather than offering two equally possible options, blessing and curse, the ceremony on $\mathrm{Mt}$ Ebal as instructed here is biased towards curse. No blessings are recited, despite their announcement; the stones are set up on the mountain of curse and the theme of curse brackets the Pentateuch. Nonetheless there is an optimism about the chapter. However this is a result of Yahweh's grace, not Israel's obedience. The provision of an altar and sacrifices and the allusions to the Abrahamic covenant in particular show that Israel stands under Yahweh's grace.

\section{Introduction}

Deuteronomy 27 issues instructions about a covenant renewal ceremony at Shechem to take place soon after Israel has crossed the Jordan and entered the land. These instructions concern the erection of large stones covered with the words of the law (vv. $2-4,8)$, the construction of an altar (vv. 5-6a), the offering of sacrifices (vv. 6b-7), the recital of blessings and curses (vv. 9-14) and the text of a dozen curses to be recited and to which the people are to respond (vv. 15-26).

Deuteronomy 27 is usually regarded as an awkward chapter both in its relationship to the chapters preceding and following it and internally. Verse 1 seems abruptly to introduce Moses in the third person, suggesting a break with chapter 26.1 Despite a common overall theme with chapter 28 , there are difficulties in relating the two chapters. Chapter 27 lists curses

\footnotetext{
${ }_{1}^{1}$ Reference to Moses in the third person occurs in Dt. 1-30 only in 1:1-5; $4: 41-5: 1 ; 27: 1,9,11 ; 29: 1-2$, though the whole book is ultimately cast in the third person. J.G. McConville, Law and Theology (JSOTSup 33; Sheffield: JSOT Press, 1984) 3.
} 
but not blessings and is concerned with the nature of the offence which provokes the curse, whereas chapter 28 deals with the nature of the curse itself. Driver suggests chapter 27 is an intrusion between $26: 19$ and $28: 1 ; 2$ others that $26: 19$ was originally followed by $27: 9.3$

In addition, Deuteronomy 27 itself is rarely regarded as a unity as its components appear to sit awkwardly with each other. Noth, without giving any details, describes the chapter as having a 'complex literary history', von Rad as having 'almost insoluble problems', Driver, as having 'considerable critical difficulties', and Mayes calls it 'very fragmentary'. ${ }^{4}$ In v. 1 , Moses and the elders address the people, though they do so in the first person singular; in v. 9 Moses is joined by the Levitical priests; in v. 11, Moses addresses the people alone. The instructions about the altar and sacrifices in vv. 5-7 are often regarded as an intrusion within the instructions about the stones and law of vv. 2-4, 8.5 Even within vv. 2-4, there seems to be an inconsistency with when the stones are to be erected. Verse 2 suggests immediately on crossing the Jordan; v. 4 is vaguer in time though because it specifically names the place as Mount Ebal, near Shechem, it seems to preclude the actual day of crossing the Jordan. In addition, there is uncertainty about whether the stones of the altar are the same as the stones on which the law was to be inscribed. Joshua 8:30-32 seems to imply they are, though most interpreters of Deuteronomy 27 argue otherwise.

Many consider there to be no obvious link between the instructions in vv. 11-14, and the twelve curses of vv. 15-26. Verses 11-14 describe a ceremony in which six tribes on Mt Ebal

2S.R. Driver, Deuteronomy (ICC; Edinburgh: T \& T Clark, 19023) 294-98.

${ }^{3}$ A.D.H. Mayes, Deuteronomy (NCBC; London: Marshall, Morgan \& Scott, 1979) 343; I. Cairns, Deuteronomy: Word and Presence (ITC; Grand Rapids: Eerdmans/ Edinburgh: Handsel, 1992) 233. Cf. G.J. Wenham, The Structure and Date of Deuteronomy (Unpublished Ph.D. thesis; University of London, 1970) 206-10, on the integral part Dt. 27 plays in the treaty structure.

${ }^{4} \mathrm{M}$. Noth, The Deuteronomistic History (JSOTSup 15; Sheffield: JSOT Press, 1981) 38; G. von Rad, Deuteronomy (OTL; London: SCM Press, 1966) 164; Driver, Deuteronomy, 294; Mayes, Deuteronomy, 340.

${ }^{5}$ E.g. Driver, Deuteronomy, 295; Mayes, Deuteronomy, 342; Cairns, Deuteronomy, 231. 
respond to six tribes on Mt Gerizim, the former with curses and the latter with blessings. However in vv. 15-26, only curses are announced and then all the people, not just the six Ebal tribes, respond by saying 'Amen'. In vv. 11-13 the Levites have no special role, they are simply one of the six tribes on Mt Gerizim; in vv. 14-26 they recite the twelve curses.

Generally scholars deal with these issues diachronically, reflecting what $\mathrm{O}^{\prime}$ Brien calls, 'a continuing preoccupation with issues of date and provenance' ${ }^{6} \mathrm{~A}$ detailed example is that of Merendino who argues for a five stage process of development of the chapter. The first stage, vv. 1a, $3 b, 5 a, 7$, derives from the time of Hezekiah when joy (v. 7) was significant. This was soon supplemented by specific instructions about the altar, vv. 5b-6 (though it is odd that the sacrifices of well-being belong to the first stage but those of the altar belong to the second stage). Later, in the time of Josiah when the solemnity of the proper public cult was important, vv. $2 b-3 a, 8$, regarding the inscribed stones were added. Then v. 4 was added, specifying Mt Ebal, and finally the deuteronomistic redactor had his say, adding reference to the elders in v. 1a, the introduction to v. 2, and 'there' in v. 5a (but not in v. 7). ${ }^{7}$

The weakness of diachronic approaches is their failure to deal with the theology of the chapter satisfactorily. What such approaches fail to recognise is that the theology of the chapter as a whole is greater than the sum of its parts. Even those commentators who presuppose or argue for the unity of the chapter almost universally fail to address the theology of the covenant ceremony. There is a resounding silence about the theological function of the altar, its accompanying sacrifices,

\footnotetext{
${ }^{6} \mathrm{M}$. O'Brien, 'The Book of Deuteronomy', Currents in Research 3 (1995) 113. ${ }^{7}$ R.P. Merendino, 'Dt 27,1-8: Eine literarkritische und überlieferungsgeschichtliche Untersuchung', BZ 24 (1980) 194-207. Similarly von Rad, Deuteronomy, 166; Driver, Deuteronomy, 300; Mayes, Deuteronomy, 344. Cf. M. Anbar, 'The Story about the Building of an Altar on Mount Ebal', Das Deuteronomium (BEThL LXVIII; ed. N. Lohfink; Leuven: Leuven University Press, 1985) 304-309; E. Nielsen, Deuteronomium (HAT I/6; Tübingen: Mohr, 1995) 245, for other reconstructions.
} 
the location of the altar and stones and the theology of the overall ceremony of curses and blessings.

It is the purpose of this article to discuss the theology of this chapter. In particular the character of Yahweh and Israel in their relationship to each other. We shall discuss this under two headings, Israel under curse, and Israel under grace. The first looks at hints of pessimism regarding the future of Israel or, in other words, the faithlessness of Israel anticipated here. The second and more optimistic thread considers Yahweh's faithfulness and grace extended to Israel.

\section{Israel under Curse}

Israel is faced with a choice: to obey or not to obey. The consequences of each option are clear: obedience results in blessings, disobedience in curses. On the surface, there appears to be a straightforward doctrine of retribution here. The question is what Israel will decide to do: obey or disobey. Obedience is the key.

However this puts the issue too simply. The two possibilities are not equally likely. Deuteronomy 27 expects Israel to fail and disobey. It is pessimistic at this level. There are a number of arguments for this pessimistic viewpoint.

\section{Absence of Blessings in vv. 15-26}

The lack of blessings corresponding to the curses of vv. 15-26 is striking. Verses 12-13 announce both blessings and curses. Indeed Seebass suggests these verses are biased towards blessing given the expression 'to bless the people' in v. 12 compared to the simpler 'for the curse' in v. 13 with no reference to the people. ${ }^{8}$ Though the latter is probably simply a circumlocution to avoid saying the tribes would curse the

\footnotetext{
${ }^{8} \mathrm{H}$. Seebass, 'Garizim und Ebal als Symbole von Segen und Fluch', Biblica 63 (1982) 22-24. Also G. Braulik, Deuteronomium II (NEB; Würzburg: Echter Verlag, 1992) 201. 'Bless' is a verb in v. 12; 'curse' is a noun. The surprise of no blessings is also heightened by the fact that the Levites in v. 12 are to bless; in vv. 14ff they announce curses. See H.D. Preuß, Deuteronomium (EDF 164; Darmstadt: Wissenschaftliche Buchgesellschaft, 1982) 151.
} 
people, ${ }^{9}$ it remains striking that only the proclamation of curses follows. When this ceremony is conducted in Joshua, both blessings and curses are recited just as it is written in the Book of the Law' (Jos. 8:34). Why, then, are there no blessings in chapter 27? Most attempts to explain this puzzle do so diachronically.

The most common explanation is that an original reversal of the twelve curses has been left out but that the text really does envision blessings as well. So Thompson says: 'The absence of a list of blessings may simply mean that they were omitted, since they would have corresponded with the curses except that they negatived every one in turn.' 10 Yet this can hardly be the case. Is it really likely that a blessing would say, 'Blessed be anyone who does not lie with any animal'? This would be so minimalist as to verge on the farcical. Similarly the theme of secrecy in the curses militates against the view that there existed a list of blessings the direct reverse of the curses. What sense would one make of the blessing on 'anyone who does not strike down a neighbour in secret'? Would someone who strikes down his or her neighbour in public be blessed? Of course not. It would be nonsensical simply to reverse the twelve curses. The same could be said for most of the other curses, the exception being the last (v. 26).

Overall, the argument that an original list corresponding to the current curses even existed, let alone was in, or is implied by, Deuteronomy 27 appears far-fetched. The text itself gives no indication that the blessings will be a simple reverse of the curses. Moreover such an explanation fails to explain why the blessings are omitted rather than the curses. So Tigay comments: 'the view that these verses do envision blessings is unconvincing; what conceivable reason could the text have had for omitting them?'11

9J.H. Tigay, Deuteronomy (JPS Torah; Jerusalem: JPS, 1996) 253.

10J.A. Thompson, Deuteronomy (TOTC; Leicester: IVP, 1974) 265. Similarly Driver, Deuteronomy, 300; P.C. Craigie, The Book of Deuteronomy (NICOT; Grand Rapids: Eerdmans, 1976) 331. This is also the view of the Mishnah; see I. Lewy, "The Puzzle of Dt XXVII: Blessings Announced, but Curses Noted', VT 12 (1962) 209.

11Tigay, Deuteronomy, 252. 
Another view seeking to explain the absence of blessings argues that 27:11-14 anticipates 28:3-6, 16-19. For example, Lewy argues that the original, northern text would have had 28:3-6, 16-19 follow 27:11-14, with 27:16-25 to follow that. The later Jerusalem redactor moved 28:3-6, 16-19 to later, expanded them into a series of sermons and reflections (Dt. 28), adding also $27: 15,26$, the former because idolatry was so serious for Jerusalemites after the fall of the Northern kingdom and the latter to include the whole of the deuteronomic law.12 However in the end this explanation for the absence of blessings is governed by the presupposition that the blessings and curses announced will be both succinct and the converse of each other. There is no necessity for either of these to be the case.

Another explanation, also supposing that 27:15-26 is an insertion, is that 27:12-14 is referring to chapter 28 as a whole. For example, Buis observes that there are two types of lists of curses in the Old Testament. One describes the person under a curse; the other the content of the curse itself. 27:15-26 fit the first category; 28:15-68 the second. Buis then goes on to argue that the root קל usually refers to the second category of curses. This root is found in 27:13 and in 28:15. So he concludes that 27:12-13 announces what is found in 28:15ff. By contrast, 27:15-26, which uses אָרוּ, continues the stipulations of the covenant. ${ }^{13}$ This distinction between the two types of curses has much to commend it. However the distinction between the two words fails to convince. pלatinguistically 27:13ff and 28:15ff have the same pattern: announces the curses; אָר follows. More importantly, Buis fails to understand the place of 27:15-26 in the current text. If these verses are a later insertion, why were they inserted here?

A number of scholars argue that the original number of curses was ten, the first and last being later additions possibly to bring the number to the number of tribes, and that the ten

12Lewy, 'The Puzzle of Dt XXVII', 210-11. Cf. Tigay, Deuteronomy, 252.

13P. Buis, 'Deutéronome XXVII 15-26: Malédictions ou Exigences de l'Alliance', VT 17 (1967) 478-79. 
provided a counterpart to the Decalogue in chapter 5.14 Certainly the first and last curses are different in form and style to the other ten; the first (v. 15) is a relative clause and not participial; the last is styled as a negative ('Cursed is the one who does not...') whereas all the others are positive. If it is the case that originally there were ten curses, though we are not convinced it is, what is the significance of framing the law with the Decalogue at its beginning and ten curses at its end? Could it be that Deuteronomy is expressing pessimism with regard to Israel's capacity to keep the law?

Merrill, though rejecting the view that originally there were ten curses, nonetheless proposes that the twelve curses do correspond 'in some way' to the Decalogue because it is clear from Joshua 8:33 that the ark, containing the Ten Commandments, was in Shechem, between Gerizim and Ebal, in the centre of this covenant ceremony, and thus it acted as a statement of blessing to counter the twelve curses. ${ }^{15}$ This attempt to balance curse with blessing both fails to convince and undermines the very theology of the passage. It fails to convince because there remain twelve curses, not ten, and the content of the twelve does not match that of the Decalogue, despite some common points. Nor is mention made of the ark in Deuteronomy 27. If the ark is intended to be a statement of blessing, why is it not included in Deuteronomy 27?

One final explanation for the absence of blessings is that of Hill. He likens the form of Deuteronomy 27 to the ancient royal land grant treaty. The Babylonian kudurru were public monuments and legal documents dealing with land transactions. The last part of their texts comprised a list of curses, without blessings, directed against any who might transgress the terms of the land grant. Though this is an

${ }^{14}$ Mayes, Deuteronomy, 346, 348; Cairns, Deuteronomy, 236; von Rad, Deuteronomy, 167; E. Bellefontaine, 'The Curses of Deuteronomy 27: Their Relationship to the Prohibitives', No Famine in the Land: Studies in Honor of John L. McKenzie (ed. J. Flanagan, A. Robinson; Missoula: Scholars Press, 1975) 51-52; Preuß, Deuteronomium, 151-52. See also Tigay, Deuteronomy, 253-54. Nielsen, Deuteronomium, 246, suggests that vv. 19, 26, which are deuteronomic in character, were added later.

15E.H. Merrill, Deuteronomy (NAC 4; Nashville: Broadman \& Holman, 1994) 347. 
attractive comparison, and may well explain the absence of blessings, nonetheless Hill fails adequately to account for the announcement of blessings in 27:12. In its implementation in Joshua 8 , he suggests that the 'ceremony of land grant is itself the blessing'. ${ }^{16}$ This is not the view of Deuteronomy 27 where blessing is associated with obedience.

None of these explanations adequately explains the absence of blessings in Deuteronomy, nor the theology of the chapter as it stands. The fact remains that Deuteronomy 27 describes a ceremony in which blessings are absent, despite the instructions of vv. 11-14. Whatever the textual history, the final version makes a theological statement biased towards curses. An accidental textual omission or insertion of such significant proportions seems unlikely. Is this, then, a deliberate ploy, implicitly acknowledging an expectation that Israel's future lies under curse and not blessing?

This was certainly the view of Martin Luther. $\mathrm{He}$ suggested that the omission of blessings in Deuteronomy 27, despite their announcement in vv. 11-13 and their recital in Joshua 8, was because 'Moses shows himself to be the minister of sin and death through the Law, which holds all under a curse (Gal. 3:10)'.17 Similarly, Keil and Delitzsch say: 'the law primarily and chiefly brings a curse upon man because of the sinfulness of his nature.'18 Though modern commentators almost universally refrain from making such theological comments, Luther and Keil's interpretations are much more satisfactory than the diachronic solutions. Keil and Delitzsch go on to draw attention, rightly, to the fact that this theological interpretation is compatible with Deuteronomy 31:16-17, which expects Israel to fail in the land, and 31:26, which regards the function of the written law as being a witness against Israel.19

\footnotetext{
${ }^{16}$ A.E. Hill, 'The Ebal Ceremony as Hebrew Land Grant', JETS 31 (1988) 403.

${ }^{17} \mathrm{M}$. Luther, Lectures on Deuteronomy (Luther's Works Vol 9; ed. J. Pelikan; trans. R.R. Caemmerer; St Louis: Concordia) 259.

${ }^{18}$ C.F. Keil and F. Delitzsch, The Pentateuch (trans. J. Martin; Grand Rapids: Eerdmans, 1951, Vol. 3) 432.

${ }^{19} \mathrm{Keil}$ and Delitzsch, The Pentateuch, 432.
} 
Driver's response to Keil's argument is intriguing. $\mathrm{He}$ concedes that Keil's view 'might explain why, for instance, in a general exposition of man's relationship to the law, the consequences of human disobedience were dwelt upon more fully and emphatically than those of human disobedience (as is actually the case in Dt. 28 and Lev. 26)'. But he ultimately rejects Keil's argument, on the grounds that 'it does not explain why, when an express arrangement has just been described for pronouncing a blessing upon the people, as well as a curse, instructions should follow for the latter, but not for the former' ${ }^{20}$ To my mind, this exposes an unwillingness to accept a theological resolution to a problem. Driver, in the end, finds the absence of blessings to be inexplicable, illustrating what I consider to be the inadequacies of a diachronic approach. Why cannot the absence of announced blessings reflect this theological view of Luther and Keil?

Admittedly sometimes diachronic approaches approximate theological interpretations. For example, Phillips, who considers Deuteronomy 27 as exilic, sees it as explaining the nation's plight as the result of covenant disobedience.21 Though this is a view of the origins of Deuteronomy which we do not share, nonetheless it is an attempt to explain the predominance of curse in this and the following chapter. However, as an explanation it falls short. Deuteronomy 27 has a literary context of anticipating the future, not explaining the present. Such a pessimistic prognosis of Israel's future says more theologically than an explanation of current exile.

Thus far, our theological explanation of the absence of blessings is perhaps plausible but not necessarily convincing. Further support for our explanation is found in the choice of Mt Ebal as the location for the stones inscribed with the words of the law. We discuss firstly the stones and then Mt Ebal.

20Driver, Deuteronomy, 300.

21 A. Phillips, Deuteronomy (CBC; Cambridge: CUP, 1973) 176. 


\section{Stones and Law}

What is on the stones? Opinions include the whole of Deuteronomy, 22 the legal section of the book (chs. 12-26), 23 the Decalogue, ${ }^{24}$ a selection of laws in Deuteronomy ${ }^{25}$ and the law of the covenant from Exodus 19-24. ${ }^{26}$

It is not impossible that the whole of Deuteronomy is intended here, despite von Rad's statement that 'surely a much shorter text' was presupposed.27 The book would fit onto just two steles the size of those on which Hammurabi's law code is written. ${ }^{28}$ In 27:8, the unusual verb בַּ is used, the same verb as at the beginning of the book (1:5), meaning to make clear, expound. The repetition of this verb may well be a sort of inclusio, suggesting that all of Deuteronomy 1-26 is to be written on the stones. ${ }^{29}$ Furthermore the expressions for law used in these verses suggest the whole deuteronomic law promulgated by Moses including the parenesis. ${ }^{30}$

What is the function of these stones? They are not purely for a record of the law, because Moses records all the words of the law in a book which is to be preserved alongside the ark of the covenant (Dt. 31:24-26). However those verses also indicate a further function of the book and shed light on the function of the stones as well. Deuteronomy 31 explicitly anticipates Israel's future failure. Moses says as much in vv. 1617.31 In addition, v. 26 states that the book containing

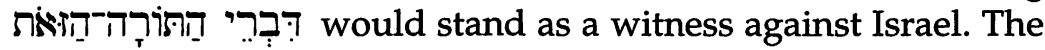

22J. Ridderbos, Deuteronomy (BSC; trans. E.M. van der Maas; Grand Rapids: Zondervan, 1984) 248; Braulik, Deuteronomium, 202.

23Driver, Deuteronomy, 296.

${ }^{24}$ Merrill, Deuteronomy, 342.

25E.S. Kalland, 'Deuteronomy' (EBC; Grand Rapids: Zondervan, 1992, Vol. 3) 160 .

26. Craigie, Deuteronomy, 328.

27Von Rad, Deuteronomy, 165.

28Tigay, Deuteronomy, 248; Cairns, Deuteronomy, 231.

${ }^{29}$ This verb occurs elsewhere in the Old Testament only in Hab. 2:2.

30See G. Braulik, 'Die Ausdrücke für "Gesetz" im Buch Deuteronomium', Biblica 51 (1970) 52-59, 64-65. Braulik assumes ch. 27 is a later insertion and thus Dt. 5-26, 28 is referred to here. See also Cairns, Deuteronomy, 231; Lewy, 'The Puzzle of Dt XXVII', 210.

${ }^{31}$ See Keil and Delitzsch, The Pentateuch, 432, who link 31:16-17 with the stones on Mt Ebal. 
context shows that this book will testify against Israel's sin and failure.

This has a bearing on how we understand the function of the inscribed stones in Deuteronomy 27. These stones are to have the same words on them as in the book in 31:24:

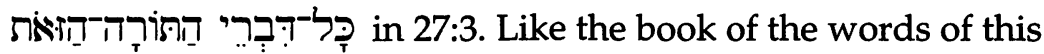
law, the stones also are to function as a witness, a common function in covenant ceremonies. Stones 'witness' Jacob's treaty with Laban in Genesis 31:44-54, and also occur in the ceremony in Exodus 24 and Joshua 24.32 The inscription of treaty texts on stones is known from the ancient world. ${ }^{33}$ Interestingly Deuteronomy 27 makes no provision for reading the law inscribed on the stones. Rather, it seems, they are to stand as a silent witness against sinful Israel.

\section{Mt Ebal}

One of the intriguing things about the instructions in $27: 1-8$ is that they are to be carried out on Mt Ebal, the mountain of curse. Why? Why are the stones and altar not set up on Mt Gerizim, the mountain of blessing? Or why are they not central, in Shechem itself?

There are two reasons behind Mt Ebal being the mountain of curse and Gerizim the mountain of blessing. Apparently, ancient Israel viewed itself as facing eastward with the Western Sea behind. Gerizim was on the south and therefore the right hand, the place of good fortune. Ebal, being on the north, was on the left hand and therefore the place of misfortune. ${ }^{34}$ This is an unusual explanation, given that Israel entered the land and approached Shechem from the east. The other explanation is that Ebal was barren and Gerizim fruitful. ${ }^{35}$ In the end, it does not matter why Ebal was the mountain of curse. Our issue is why the mountain of curse is where the stones and altar are to be erected.

32Tigay, Deuteronomy, 247.

33Tigay, Deuteronomy, 247. E.g. J.B. Pritchard (ed.), The Ancient Near Eastern Texts Relating to the Old Testament (Princeton: Princeton University Press, $\left.1969^{3}\right), 659$.

${ }^{34}$ Driver, Deuteronomy, 132; Mayes, Deuteronomy, 217-18.

${ }^{35}$ Mayes, Deuteronomy, 218, citing Bülow. 
Few commentators even note that Ebal is a curious location for the stones and altar. ${ }^{36}$ Some of those who do make comment, in an attempt to explain the oddness of Ebal, note that the Samaritan version has Gerizim in place of Ebal in vv. $1-8$. This is usually regarded as an ideologically-motivated alteration and not original, though there are those who suggest the reverse. Phillips suggests that after the Samaritan schism, the Jews, and not the Samaritans, altered Gerizim to Ebal for polemical reasons. ${ }^{37}$ Cairns, who argues that Gerizim is the more likely original location because the torah brings blessing, claims that the view that Gerizim is the original reading is gaining ground. ${ }^{38}$ Nonetheless the majority opinion remains firmly of the view that the original location was Ebal, not Gerizim. ${ }^{39}$ Even if the Jews did want to change the text as an anti-Samaritan polemic, why not exchange Ebal and Gerizim in vv. 11-14 so that Ebal was the mountain of blessing? That would have been just as important as changing vv. 1-8.

What theological statement is being made by Mt Ebal being the place for the stones? The placement of the stones of the law on the mountain of curse suggests that at least one function of the law is to expose the sinfulness of Israel and bring it under the curse of the law. The expectation is that Israel will disobey. 40 In the end, obedience is not a realistic possibility.

We have seen that the absence of blessings in chapter 27 , the function of the stones as a witness against Israel, as well the choice of $\mathrm{Mt}$ Ebal for the inscribed stones, function as expressions of the same theological perspective. The law brings

\footnotetext{
${ }^{36}$ E.g. Keil and Delitzsch, The Pentateuch, 431-32; Ridderbos, Deuteronomy, 249; D.T. Olson, Deuteronomy and the Death of Moses (OBT; Minneapolis: Fortress Press, 1994) 117.

37Phillips, Deuteronomy, 179; Mayes, Deuteronomy, 341.

${ }^{38}$ Cairns, Deuteronomy, 231-32. Von Rad, Deuteronomy, 165, also considers that the altar is to be built on Mt Gerizim.

${ }^{39}$ Craigie, Deuteronomy, 328; Merrill, Deuteronomy, 343; J.G. McConville, 'Time, Place and the Deuteronomic Altar Law', in J.G. McConville and J.G. Millar, Time and Place in Deuteronomy (JSOTSup 179; Sheffield: Sheffield Academic Press, 1994) 97.

40 Olson, Deuteronomy, 117.
} 
Israel, sinful as it is, under the curse of the law. The nature of the final curse further contributes to this argument.

\section{Secrecy and the Final Curse}

Two of the curses deal explicitly with crimes committed in secret: the first (v. 15) with idols in secret, and the tenth (v. 24) with striking a neighbour in secret. A number of scholars have suggested that the motif of secrecy runs through these verses. Though this is disputed, 41 Bellefontaine has argued persuasively that the secrecy motif is significant since each of the curses relates to an already known prohibitive which carries its own legal prescriptions of punishment. In this list, the invocation of curses goes beyond the legal prescriptions of punishment and is a recognition that in the secret places of the heart, only Yahweh can judge and implement the curses. 42 The curses thus function to warn those who think they could safely violate the covenant in private.

Tigay suggests that these twelve curses form a parallel with 29:17-28 where Moses warns Israel that secret sins will be detected by Yahweh and punished.43 If this connection is valid, it contributes to the pessimistic expectation that Israel is under the curse, for Deuteronomy 29 portrays the inevitability of curses coming on Israel in the future. While such a negative assessment of Israel is not explicit in chapter 27, there remains an implied negative assessment of Israel in these curses.

The final curse, which unlike the preceding eleven is expressed negatively ('Cursed be anyone who does not...'), does not apply to one item of the law but to the law as a whole, showing that the curse comes on anyone who breaks any part of the law. Thus the first eleven curses function as examples for which the principle is found in v. 26. The implication of this is

${ }^{41}$ E.g. Cairns, Deuteronomy, 237. Contrast Keil and Delitzsch, The Pentateuch, 434; Driver, Deuteronomy, 299-300; Craigie, Deuteronomy, 331; C.J. Wright, Deuteronomy (NIBC 4; Peabody: Hendrickson, 1996) 277.

42Bellefontaine, 'The Curses of Deuteronomy 27', 58-59. Also A. Alt, 'The Origins of Israelite Law', Essays on Old Testament History and Religion (trans. R.A. Wilson; Sheffield: JSOT Press, 1989) 114-15; M. Weinfeld, Deuteronomy and the Deuteronomic School (Oxford: OUP, 1972) 276-79; Olson, Deuteronomy, 118-19.

${ }^{43}$ Tigay, Deuteronomy, 254. See especially 29:19. 
that v. 26 shows how demanding obedience to God is. Whereas it is possible to imagine someone who obeys the first eleven laws in vv. 15-25, it is harder so to do for v. 26. Is this verse, therefore, contributing to the pessimistic view that Israel stands under curse? Martin Noth certainly thought so, and wrote:

On the basis of this law there is only one possibility for man of having his own independent activity: that is transgression, defection, followed by curse and judgement. And so indeed, 'all those who rely on the works of the law are under a curse'.44

\section{Canonical Shaping of the Pentateuch}

There are various canonical approaches to the Pentateuch which lend support to the theology we have outlined. Sailhamer argues from a canonical perspective that the Pentateuch is pessimistic about the future of Israel. Taking up an argument of Schmitt regarding the theme of faith which occurs at crucial redactional seams in the Pentateuch, Sailhamer argues that the Pentateuch contrasts Abraham and Moses. The former exhibits a life of faith before the law; the latter, life without faith under the law. All the references to faith up to and including Exodus 19:9 are positive; all those which follow are negative. Thus the Pentateuch's view of the Mosaic law is essentially negative. Little hope is held for blessing under the law. 45

A more convincing argument is that of Dempster, who argues that 'at the end of the Torah there is a remarkable clustering of themes that echo those at the beginning' ${ }^{46}$ These

${ }^{44} \mathrm{M}$. Noth, 'For All who Rely on Works of the Law are Under a Curse', The Laws in the Pentateuch and Other Essays (trans. D.R. Ap-Thomas; Edinburgh: Oliver and Boyd, 1966) 131. See F.F. Bruce, "The Curse of the Law', Paul and Paulinism: Essays in Honour of C.K. Barrett (ed. M.D. Hooker, S.G. Wilson; London: SPCK, 1982) 27-30, on this verse as understood in Gal. 3.

45J.H. Sailhamer, 'The Mosaic Law and the Theology of the Pentateuch', WTJ 53 (1991) 24-61; H-C. Schmitt, 'Redaktion des Pentateuch im Geist der Prophetie', VT 32 (1982) 170-89.

465. Dempster, 'An "Extraordinary Fact": Torah and Temple and the Contours of the Hebrew Canon', TynB 48 (1997) 56. 
include God's 'power-laden' words offering life or death through obedience and disobedience in Genesis 2 and Deuteronomy 30:15-20. Disobedience results in expulsion, from Eden or from the promised land. Obedience results in fellowship with God within Eden or the land. Like Adam and Eve at the end of Genesis 3, Israel stands east of Eden. In both Genesis 1 and Deuteronomy 32:46-47, God himself is the source of life through his life-giving word.47

Dempster's argument about the deliberate canonical shaping of the Torah is substantial. Though he does not comment on Deuteronomy 27, curses are another theme which reflect a canonical shaping of the Pentateuch. Admittedly Dempster does briefly acknowledge the place of curse in key places in the Old Testament, namely in Genesis 3, Joshua 7, and Psalms 1-2, the beginning of each of the three sections of the Hebrew Bible. ${ }^{48}$ However the theme of curse also brackets the Pentateuch. In Genesis 3-4, near the beginning of the Pentateuch, humanity fails to obey God's word and God's curses ensue. Near the end of the Pentateuch, God's people, also outside the place of God's presence, hear a recital of curses. Given the failure of humanity in Genesis 3-4, and the programmatic place of these chapters at the head of the Old Testament, ${ }^{49}$ the outlook is ominous. The expectation is that the new humanity, like the first, will stand under the curse of the law. Adam and Eve failed to respond correctly to the tree of the knowledge of good and evil; Israel, by implication, will fail to choose good rather than evil (Dt. 30:15-20).50

\section{Beyond Deuteronomy 27}

The theological understanding of Israel being under the curse is consistent with what we find elsewhere in Deuteronomy. Chapter 28 lists both blessings and curses but curses predominate. Only fourteen verses are devoted to blessings but

\section{Ibid, 49-56.}

48Ibid, 216.

${ }^{49}$ See J.G. McConville, "The Shadow of the Curse: a "key" to Old Testament Theology', Evangel 3.1 (1985) 2-6.

50P.A. Barker, Faithless Israel, Faithful Yahweh in Deuteronomy (Unpublished Ph.D. Thesis, University of Bristol, 1995) 235-56. 
fifty-four verses to curses, suggesting a greater likelihood of disobedience. 51 Though a predominance of curse over blessing is not unusual in the sanctions of ancient Near Eastern treaty texts, it is not universally the case, especially with Hittite treaties.52 Deuteronomy is not slavishly following any ANE pattern but is making a theological statement about the imbalance between curse and blessing, an imbalance which is exacerbated by the curses without blessings of chapter 27.53 Indeed the few blessings of 28:1-14 are surrounded by curses.

This weighting in favour of curses spills over into inevitability in 28:45-48. No longer is the curse a conditional possibility dependent on Israel's free choice; now; instead, it is 'a declared state of fact that will happen in the narrated future'. ${ }^{54}$ The seeds of such explicit expectation are embedded in chapter 27.

This expectation continues in the following chapters. We have already briefly commented on chapter 29 which anticipates unchecked sin in Israel and 'all the curses written in this book' descending on Israel (v. 20). Though blessings will subsequently follow (30:1-20), these will only come after the curses (30:1). We have also noted above the clear expectation of Israel's failure stated in 31:16-29 and the function of the book containing 'all the words of this law', along with the Song of Moses, as witnesses against faithless Israel. Thus the chapters following Deuteronomy 27 add to our argument that Israel stands under the curse. The two options of obedience and disobedience held out before Israel are not equally possible. Israel will fail and be under the curse.

It could be objected that the tribal blessings of Deuteronomy 33 challenge the view that the last chapters of Deuteronomy are pessimistic. However the blessings of the

51Noth, 'For All who Rely', 120-26.

52D.J. McCarthy, Treaty and Covenant: A Study in Form in the Ancient Oriental Documents and in the Old Testament (AnBib 21A; Rome: Biblical Institute Press, 1981) 173.

53So P.D. Miller, Deuteronomy (Interpretation; Louisville: John Knox Press, 1990) 194; Olson, Deuteronomy, 117; J.E. Goldingay, Theological Diversity and the Authority of the Old Testament (Grand Rapids: Eerdmans, 1987) 155. ${ }^{54}$ Olson, Deuteronomy, 122. 
dying Moses are of a different ilk than those of Deuteronomy 27-28. Blessing in chapter 33 is not bound to the law but ultimately derives from Yahweh's grace. Thus Deuteronomy 33 supports our overall thesis, for it is an expression of optimism, with confidence placed not in Israel's possibility of covenant obedience, but in Yahweh's grace, a point which we will develop below.

The pessimistic expectation is not confined to the last chapters of the book. Two particular cases of Israel's past failure are rehearsed earlier in the book: the failure to enter the land in the spies incident (ch. 1), and the golden calf incident (ch. 9). I have shown elsewhere that in both episodes, Deuteronomy demonstrates that the current generation of Moses' hearers is no different from their parents' generation. Through various rhetorical devices (such as the conflation of generations; e.g. 5:2), the current generation's culpability and vulnerability to $\sin$ are shown. ${ }^{55}$ Indeed Deuteronomy goes to lengths to expose Israel's sinfulness. 56

It is well known that chapter 27 forms a bracket with 11:26-30 around the law. Though 11:26-30 does not detail any curses or blessings, and appears open to the possibility of either curse or blessing, the likelihood of curse is evident. Given Israel's persistent faithlessness rehearsed in chapters 1 and 9, the reader of 11:26-30 must be dubious, at best, about the possibility of Israel obeying and incurring a blessing. Chapter 27 rounds off the law, indicating how we are to understand Israel's capability to fulfil it. As Olson says: 'The curses at the end of the statutes and ordinances recognize the limitations of human capacities to monitor and mold human beings into people so that they do what is good, just and holy, and in accord with God's will.'57

55Barker, Faithless Israel, 30-34. See also J.G. Millar, 'Living at the Place of Decision: Time and Place in the Framework of Detueronomy', in Time and Place in Deuteronomy, 15-88; K.A. Deurloo, 'The One God and All Israel in its Generations', Studies in Deuteronomy (FS. C.J. Labuschagne; ed. F. García Martínez, A. Hilhorst, et al.; Leiden: E.J. Brill, 1994) 37-46.

56Ridderbos, Deuteronomy, 249; also Luther, 259-61.

57Olson, Deuteronomy, 118-19. 
Finally, it is interesting to compare the covenant ceremony in Exodus 24:3-9 with Deuteronomy 27. In Exodus 24 , as in Deuteronomy 27, the words of the law are written, an altar built and burnt offerings and sacrifices of well-being are made. In Exodus 24, the people whole-heartedly announce their intention to obey everything which God has commanded. In fact, this pledge is made twice (vv. 3,8). It is striking that, in Deuteronomy 27, Israel is commanded to keep silence (v. 9) and the only word Israel is to speak is 'Amen' in response to each curse. The emphatic optimism of Exodus 24 has evaporated. Israel had failed to keep its pledge of Exodus 24, a history of which Deuteronomy is all too well aware. In light of this, perhaps the silence of Deuteronomy 27 indicates an implicit pessimism regarding the future. 58

\section{Israel under Grace}

We have argued that Deuteronomy 27 is pessimistic with respect to the possibility of Israel's obedience to the covenant law. However this chapter is not so straightforward. Curse is not the final word. The ceremony acknowledges a future for Israel, not premised on Israel's ability but rather on Yahweh's faithfulness. There are four points in support of this argument.

\section{Altar and Sacrifices}

The theological contribution of the altar and sacrifices in vv. 5-7 is mostly ignored by commentators who more frequently concern themselves with the compatibility of these instructions with the sanctuary law of chapter 12,59 or with source-critical, diachronic issues, often regarding the verses as a later addition. For example, Anbar argues that vv. 5-7 were inserted to link the Shechem covenant back to the Sinai covenant by extrapolating from the altar law of Exodus 20:24-25. In the end, he fails to

58See also Barker, Faithless Israel, 240-45, on the optimism of Jos. 24:16-18 and Israel's silence in Dt. 30:15-20.

${ }^{59}$ On the compatibility of this passage with Dt. 12, see McConville, Time, Place and Deuteronomic Altar Law', 120; J.J. Niehaus, 'The Central Sanctuary: Where and When?', TynB 43 (1992) 9-10. 
explain why an 'insertion' of vv. 5-7 links the two covenants which appear already linked in vv. 2-4, 8.60

Most commentators understand the theology of this ceremony to be law-centred, that Israel's relationship with God (or its standing as his people; v. 9), is based on its obedience to the law. So, Tigay notes that v. 8 , which mentions the inscription of the law, recapitulates v. 2 and thus brackets the instructions about the altar and sacrifices, thereby showing that the teaching or law is central to this ceremony. ${ }^{61}$ However it is possible to argue the other way round, that at the heart of the instructions about the law lie instructions about the altar and sacrifices. It may even be that there is a chiasm here as follows:

A Moses; Command to keep commandment (v. 1)

B Instruction to write on stones (vv. 2-4)

C Instructions concerning altar and sacrifice (vv. 5-7)

B' Instruction to write

$\mathrm{A}^{\prime} \quad$ Moses; Command to obey commandment (vv. 9-10)

It is probably going too far to push a chiastic structure in this case. Though a chiasm may explain the repetition of writing on the stones in v. 8, it does not explain the repetition of v. 4 (unless vv. 2-4 are themselves chiastic). Also, though vv. 9-10 have some links with v. 1 (in both, Moses is mentioned by

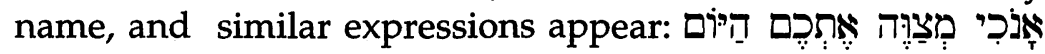

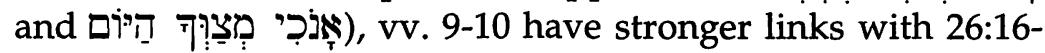
19.62 But whether or not these verses are formally chiastic, the altar and sacrifices lie at the heart of the Mt Ebal ceremony. Central, therefore, to an understanding of law, is the facility for sacrifice.

The instructions for building the altar of uncut stones follow the law of Exodus 20:24-25. The combination of burnt offerings and sacrifices of well-being occurs thirteen times in the Old Testament and is often associated with significant occasions, such as: (1) Exodus 20:24 and 24:5, at the conclusion

${ }^{60}$ Anbar, 'The Building of an Altar', 304-309.

61Tigay, Deuteronomy, 250.

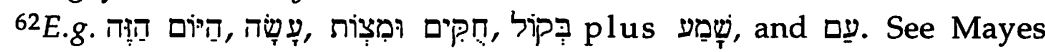
Deuteronomy, 343. 
of the covenant at Mt Sinai, and (2) Joshua 8:31, which describes the fulfilment of the instructions here in Deuteronomy 27.63

The first type of sacrifice to be offered on Mt Ebal was a burnt offering in which the whole animal was totally consumed by fire. Though there is debate about the manner and degree to which burnt offerings atoned, there are enough indications within the Old Testament that there is an underlying association between burnt offerings and atonement. It need not concern us here whether atonement is effected by cleansing, by blood manipulation, by the sacrifice being a gift to appease God, or by the laying of the hand. Even though sin and guilt offerings appear to be the primary means of atonement within the tabernacle and temple system, outside of it and before it, the burnt offering was the primary means of atonement. 64 The point is that atonement is being made by the burnt offerings on Mt Ebal, presumably for the sins which the inscribed stones expose.

The burnt offerings are followed by sacrifices of wellbeing, שְְִׁמִים, variously translated as peace or fellowship offerings. This is the only time they occur in Deuteronomy. Usually not all the meat of this offering was consumed by the sacrifice; rather the people consumed most of it in a communal meal, which appears to be the main focus of this offering. This meal was a joyful celebration of peace between God and his people, indicating that the people were in a state of well-being. Understandably, wherever sacrifices of well-being were included in any series of offerings, they are always positioned last in the series. 65

The sequence of law stones, burnt offering and sacrifice of well-being is instructive for understanding the theology of

${ }^{63}$ See Tigay, Deuteronomy , 250. Other examples include 1 Sa. 13:9; 2 Sa. 6:18.

64J. Milgrom, Leviticus 1-16 (AB; New York: Doubleday, 1991) 176; R.E. Averbeck, 'עפלדיה', in W.A. Van Gemeren (ed.), New International Dictionary of Old Testament Theology and Exegesis (Grand Rapids: Zondervan, 1997) vol. 3, 409-13. Averbeck argues that burnt offerings continued to have an atoning function even in the sanctuary system, e.g. Lv. 16:24, even on the Day of Atonement.

65R.E. Averbeck, 'שֶׁ? 342-43. 
the chapter. The inscribed stones of law on the mountain of curse expose Israel's sinfulness and indicate that Israel stands under a sentence of curse. Yet, at the very place of curse, Yahweh provides a means of avoiding such a sentence. The altar and the instruction for burnt offerings are a gracious provision of a means of atonement to a sinful people. Only when sin is atoned can the sacrifices of well-being be made. They are a tangible demonstration of the effectiveness of the burnt offering and the subsequent restored relationship between Yahweh and Israel. Eating the meal reenacted the bond of relationship established between Yahweh and Israel.66 The meal would remind Israel that the covenant relationship was based on grace and was sustained by the gracious provision of sacrifices. 67

The expectation in this chapter of Deuteronomy is that Israel will fail to keep the covenant stipulations. However the bottom line in the relationship between Yahweh and Israel is Yahweh's grace, which overcomes Israel's faithlessness.

\section{Shechem and Abrahamic Promise}

The second point in support of a relationship established and sustained by Yahweh's grace concerns the place where this ceremony occurs. The site is Shechem, the place where the promise of land was first made to Abram (Gn. 12:7), the place where Jacob bought a plot of land (Gn. 33:19) and the place where Joseph's bones are later buried (Jos. 24:32).68 The building of an altar here perhaps strengthens the connections with Genesis 12:6-7 and 33:18-20.69 This is therefore a highly appropriate place for such a ceremony, the place being an expression of Yahweh's faithfulness to his promises to Abraham. Verse 3 draws this out in typical deuteronomic language, describing the land as that which 'the Lord, the God

\footnotetext{
66R.E. Averbeck, 'Offerings and Sacrifices', NIDOTTE , vol. 4, 1001.

${ }^{67}$ R.H. Munchenberg, Deuteronomy (ChiRho; Adelaide: Lutheran Publishing House, 1986) 183.

68It is also a place of failure in Gn. 34, a background which may also contribute to the theme of Israel under curse.

${ }^{69}$ Nielsen, Deuteronomium, 246.
} 
of your fathers, promised you'. It is little wonder that this is the place Israel is to head for after crossing the Jordan.

However there is debate about whether Gilgal is intended rather than Shechem. Verses 2 and 4 appear to stand in tension. The former is often regarded as implying that the ceremony is to be held the very day Israel crosses the Jordan, in which case Gilgal is an obvious candidate for the location. The latter explicitly refers to Mt Ebal, which would be too far to reach from the Jordan in a day. The usual (diachronic) resolution to this problem considers $\mathrm{v} .4$ as a later addition, subsuming an early Gilgal tradition into a later Shechemite tradition. ${ }^{70}$ It would be an incompetent redactor who would make such a geographical blunder by not altering v. 2 as well.

More likely the so-called tension between the two verses is overstated. $\square$ ' need not refer to a particular 24-hour period. Genesis 2:4 is a classic example, where ביוֹם + the infinitive refers to the seven day period of Genesis 1:1-2:3. The

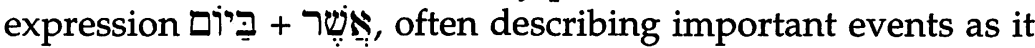
does in 27:2, also need not refer to a particular day. ${ }^{71}$ In addition, in Deuteronomy, $\square$ i' is used rhetorically. Thus, the concern of Moses 'is not with the 24-hour period beginning with the crossing of the Jordan-it is much more profound than that. Rather he demands that the 'day of decision' of Moab becomes the 'day of response' of Canaan'.72 Maybe the sense of immediacy in v. 2 reflects priority rather than chronology, or possession of the land rather than entering the land. ${ }^{73}$ So the arguments that vv. 2 and 4 have differing perceptions of time and that Gilgal, not Shechem, was the original location of this

${ }^{70}$ E.g. Mayes, Deuteronomy 218-19, 340-41; Merendino, 'Dt 27,1-8', 202-203. Cf. Nielsen, Deuteronomium, 247.

${ }^{71}$ E. Jenni, 'ㄷ', in E. Jenni and C. Westermann (eds.) Theological Lexicon of the Old Testament (trans. M.E. Biddle; Peabody: Hendrickson, 1997) vol. 2, 529-30. Cf. Tigay, Deuteronomy, 486.

${ }^{72}$ Millar, 'Living at the Place of Decision', 72. See also Thompson, Deuteronomy, 263; P.A. Verhoef, 'םi', NIDOTTE, vol. 3, 423.

73Merendino, 'Dt 27,1-8', 203. 
ceremony are weak. ${ }^{74}$ Shechem, with its association of covenant promise, is in mind in Deuteronomy 27.

This association with covenant promise is also strengthened by the argument of Hill that Deuteronomy 27 reflects an ancient royal land grant. Though we are not convinced by every detail of his argument, as noted above, the land grant treaty binds the suzerain to the vassal and not vice versa, as in the more well-known Hittite vassal treaties. In chapter 27 Yahweh is binding himself, unconditionally, to Israel, declaring them to be his people (v. 9) and assuring them of the gift of the land (v. 3).

Shechem, and its association with covenant promise, therefore, establishes a context of grace for this ceremony, the importance of which cannot be overstated. 75 What we have found in Deuteronomy 27 is found throughout the book. Indeed Deuteronomy is framed by references to the Abrahamic promises in 1:6-8 and 34:4. What is most significant is the place of the Abrahamic promises in the context of Israel under curse. In the spies incident and its resolution in chapters 1-3, it is Yahweh's faithfulness to the Abrahamic promises, expressed in $1: 8,35$, which frame the episode (also alluded to in 1:21, 25, 32). It is Yahweh's faithfulness to his promise which ensures a future for Israel. Likewise, in the resolution of the golden calf incident, it is Yahweh's response to Moses' appeal to the Abrahamic promises in his prayer in 9:25-29 which ensures Israel's future. Thirdly, anticipating future rebellion in the land in chapter 29, it is Yahweh's faithfulness to the Abrahamic promises which undergird the promises of restoration in 30:110.76 This pattern also applies in Deuteronomy 27. Israel, its sin exposed by the law and standing under a curse, has a future with Yahweh because of the promises made to Abraham, notably at Shechem in Genesis 12:7.

Thus the theology we have argued for in Deuteronomy 27 is consistent with that found elsewhere in the book. Hope for

${ }^{74} \mathrm{Cf}$. Hill, 'The Ebal Ceremony', 404-406, who argues that Gilgal and Shechem are a twofold implementation of this ceremony in Jos. 4 and 8. Yet there is nothing in Dt. 27 to suggest a two-stage implementation. 75Wright, Deuteronomy, 276.

76Barker, Faithless Israel, 35-42, 109-14, 199-205. 
Israel is grounded in Yahweh's grace, mercy and faithfulness to the Abrahamic promises, and not in the potential of Israel to obey the law. The ceremony of Deuteronomy shows this. Israel stands condemned under the law, but the ceremony also graciously provides the means for a future and ongoing covenant relationship with Yahweh through the altar and sacrifices on the mountain of curse.

\section{People of God (vv. 9-10)}

The pre-eminence of grace is further illustrated in vv. 9-10. Deuteronomy has frequently acknowledged that Israel is already Yahweh's people (e.g. 7:6; 14:1-2). Moses and the Levitical priests declare that Israel has now 'become the people of Yahweh your God' (v. 9). What is the import of this statement?

In vv. 9-10, the order of the clauses is important. The declaration of the relationship precedes the command to obey in v. 10, which makes clear that obedience is to be a consequence of the relationship, not its cause. 77 Therefore Israel's status as God's people is Yahweh's initiative and is independent of its obedience to the law. This is brought out by

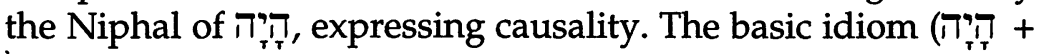
?) is familial and has to do with being in a relationship with someone. As Tigay says: 'Here it means "you were caused to become": Israel became God's people by an act of God.'78 Israel stands under Yahweh's grace.

Furthermore, this verse recalls Yahweh's declaration in Exodus 19:5-6 that Israel is his special people. Indeed 26:16-19, to which 27:9-10 are often regarded as the original continuation, ${ }^{79}$ has already alerted the reader to the context of Exodus 19 with clear verbal parallels ('treasured possession', 'people holy to the Lord'). At Sinai the exodus generation was

77Cairns, Deuteronomy, 234; Thompson, Deuteronomy, 264; E.J. Hamlin, $A$ Guide to Deuteronomy (SPCK International Study Guide 32; London: SPCK, 1995) 153-55; Braulik, Deuteronomium, 201. Cf. Phillips, Deuteronomy, 179: the 'election (of Israel) is dependent on her obedience to his law'.

78Tigay, Deuteronomy, 251; Weinfeld, Deuteronomy, 80-81; Nielsen, Deuteronomium, 247. The expression occurs only here in the OT.

${ }^{79}$ See above. 
declared to be God's people. Now, at another strategic point in Israel's history, the conquest generation is affirmed in the same relationship with Yahweh. As the covenant relationship declared in Exodus 19 was premised on grace, so the same applies for the next generation, as the repeated 'as he promised' in 26:18, 19 highlights. Just as obedience was a consequence of the covenant relationship at Sinai, so the same is true for the next generation. Just as the conquest generation is already the people of Yahweh before $\mathrm{Mt}$ Ebal, so was the exodus generation before Mt Sinai (Ex. 3:7). Just as the Sinai declaration was made to a grumbling, rebellious people, so is the Ebal declaration. What is in mind is a formal acknowledgement of a pre-existing relationship, initiated by Yahweh but demanding covenantal obedience in response to his grace.

Israel is declared, here in the Plains of Moab, to be Yahweh's people. The ceremony to be held at Mt Ebal will formally ratify that relationship. Thus the theology of the Mt Ebal ceremony is covenantal, reflecting a relationship instigated and sustained by Yahweh's grace and demanding as consequence, Israel's obedience. The issue is covenant renewal for the new generation.

\section{Canonical Shaping of Pentateuch}

Our final point picks up the canonical approach raised in the first part of this paper. At the beginning of the Pentateuch, Adam, Eve and Cain not only stand under divine curse but are also the recipients of God's grace. The first two are clothed, the last one marked for his protection. Though Adam and Eve are expelled from the garden, and Cain is sent further east, all three are kept alive. All deserved death, but God's mercy and grace kept them alive, at least in the short term. Likewise Israel in Deuteronomy 27, even in the midst of curses and outside the land which represents God's sanctuary, receives Yahweh's gracious provisions of an altar and sacrifice so that the covenant relationship with him can continue despite failure and the people continue to live. 


\section{Conclusion}

The ceremony at Mt Ebal in Deuteronomy 27 reflects a nuanced theology of Israel under curse yet also under grace. The instructions of vv. 1-7 lead from the exposure of Israel's sin through the inscribed stones, to atonement for sin through burnt offerings and then to a celebration of restored relationship with Yahweh through the sacrifices of well-being. Rather than two equally possible options being held out for Israel to choose from (namely blessing/obedience and curse/disobedience), the chapter indicates an expectation of failure. Law is unable to bring blessing because Israel is sinful. Yet the thread of grace running through this chapter warns us not to expect a simple doctrine of retribution. The theology is more nuanced than that. Despite its faithlessness, Israel can continue in a relationship with Yahweh because of his overarching faithfulness. Yahweh, then, is both holy, as the inscribed stones and subsequent curses show, and full of grace, as the altar and sacrifices show.

This theological movement within vv. 1-7 from curse to grace is also found in the following chapters. From 27:8 to the end of chapter 29 we find the expectation and inevitability of curse. Yet the story does not end in exile and failure but continues with Yahweh's gracious restoration of Israel in chapter 30 . Thus 27:1-7 foreshadows the pattern found in 27:830:14.

The theology we have been describing also accounts for the differing strands of pessimism and optimism. Rather than being opposed to each other, these two themes stand in creative tension. Pessimism is found in Israel's faithlessness; optimism in Yahweh's faithfulness. In the end, the latter will triumph. 80

Modern commentaries on this chapter have shown a paucity of theological appreciation. In the end, the Bible is a theological document and where the theology of a passage is either not grappled with or ignored, then commentary has failed to explain the passage adequately. Maybe, as a colleague

80So J.G. McConville, Grace in the End (SOTBT; Carlisle: Paternoster Press, 1993) 
mused, commentators have run out of steam by chapter 27. Maybe the predominance of diachronic analysis has blinded scholars to the importance of theology. Diachronic methods necessarily diminish theology, for wherever tension is found, separation of sources or redactions is supposed, the end result being reductionistic theology. Perhaps the trends to synchronic analysis in Old Testament studies may correct this deficiency. It is surely the task of evangelical commentators to plumb the theological depths and soar to the theological heights of the Old Testament if we are to understand better the God of all grace. ${ }^{81}$

${ }^{81}$ This article was delivered as the Old Testament Lecture, Tyndale Fellowship, 1998. 